\title{
Estimating Mortality in Laying Hens as the Environmental Temperature Increases
}

\section{Author(s)}

Pereira DF

do Vale $\mathrm{MM}^{2}$

Zevolli $\mathrm{BR}^{3}$

Salgado $\mathrm{DD}^{4}$

UNESP - Univ Estadual Paulista, Campus de Tupã, SP

2 Universidade Federal de Santa Maria - RS. Departamento de Zootecnia, UFSM.

3 UNESP - Univ Estadual Paulista, Campus de Tupã, SP E-mail: braianzevolli@msn.com

4 Pontifícia Universidade Católica, Dep. de Matemática. Campinas, SP.

\section{Mail Address}

\section{DF Pereira}

Univ Estadual Paulista

Campus Experimental de Tupã

Av. Domingos da Costa Lopes, 780. Jd. Itaipu

17.602-496. Tupã, SP, Brasil.

E-mail: danilo@tupa.unesp.br

\section{Keywords}

Data mining, layer production, mortality, thermal comfort.

\section{Acknowledgements}

The authors thank the Association of Farmers of Bastos, and their employees for their support.

\section{ABSTRACT}

Layer mortality due to heat stress is an important economic loss for the producer. The aim of this study was to determine the mortality pattern of layers reared in the region of Bastos, SP, Brazil, according to external environment and bird age. Data mining technique were used based on monthly mortality records of hens in production, 135 poultry houses, from January 2004 to August 2008. The external environment was characterized according maximum and minimum temperatures, obtained monthly at the meteorological station CATI in the city of Tupã, $\mathrm{SP}$, Brazil. M ortality was classified as normal $(\leq 1.2 \%)$ or high $(>1.2 \%)$, considering the mortality limits mentioned in literature. Data mining technique produced a decision tree with nine levels and 23 leaves, with $62.6 \%$ of overall accuracy. The hit rate for the High class was $64.1 \%$ and $59.9 \%$ for Normal class. The decision tree allowed finding a pattern in the mortality data, generating a model for estimating mortality based on the thermal environment and bird age.

\section{INTRODUCTION}

Egg production is an important economic activity for Brazilian animal production. The state of São Paulo has $31.6 \%$ of the national layer flock, which is much higher than the second largest flock of $11.8 \%$, located in M inas Gerais (UBA, 2009). However, during the first half of 2009 , there was a monthly reduction of $1.68 \%$ in egg production (UBA, 2009) as a reflex of market demand. Egg production activity sells to a very competitive market, demanding significant effort to reduce costs.

Few researchers have studied the effect of weather on productivity, product quality, and animal welfare. The selection for higher production has increased the susceptibility of poultry to heat stress, and making the search for mitigation actions difficult (Nardone et al., 2006).

Layer mortality due to heat stress, usually observed during heat waves, is a significant economic loss for egg producers. The municipality of Tupã, $\mathrm{SP}, 20 \mathrm{~km}$ distant from the main egg-producing region in Brazil, presents a high risk of the occurrence of heat waves (Salgado, 2008).

During layer production cycle, a determined mortality rate expected. Genetic company management manuals (Dekalb, 2009; Hy-Line, 2009; Lohmman, 2009) indicate acceptable mortality rates between 0.8 and $1.5 \%$ per week. However, these numbers are sometimes exceeded, and there are few studies that investigate this dynamics, which is typical of outlier data analysis. In broilers, the increase in mortality rates caused by heat waves was studied by Vale et al. (2008), but no studies with layers were found.

According to the studies carried out by the IPCC (Intergovernmental Panel on Climate Change), extreme climatic events, such as heat waves, 
will become more frequent and intense due to global warming (Marengo, 2007), and therefore, research on the impact of climate on animal production is of utmost importance.

The use of data mining, as proposed by Fayyad \& Stolorz (1997), has been applied in poultry production to investigate layer breeder flocks (Lima, 2007), to predict climatic events (Vale, 2008), and to describe mortality causes (Vale et al., 2008), and has promoted important developments in the know ledge, description, and prediction of climatic events.

This study aimed at determining the mortality pattern of egg-producing layers reared in the region of Bastos, $\mathrm{SP}$, Brazil, as a function of external environment and flock age.

\section{MATERIALS AND METHODS}

Monthly mortality data of layer flocks reared in Bastos, SP, Brazil, were analyzed. Data from January, 2004 to August, 2008, were obtained from the Association of Egg Producers of that municipality.

Each layer house supplied a data bank subset, represented by the average monthly mortality of a flock (house). These data were later integrated to the summary of meteorological data corresponding to the month of that layer flock.

Data on the external environment of that region were obtained at the CATI weather station, located in the county of Tupã, SP, located about $20 \mathrm{~km}$ from Bastos.

The county of Bastos is located in the Alta Paulista region, in the west of the state of São Paulo, in a region characterized as Aw in Köppen's classification (Rolim et al., 2007).

In Bastos, layers are predominantly reared in battery cages, and all layer houses analyzed in the present study presented this rearing system. All housed were made of wood, with clay, asbestos, or zinc roof.

\section{Methodology}

A descriptive data analysis was first carried out on the distribution and time variability patterns of the data using $\mathrm{M}$ initab ${ }^{\circledR}$ software program

Based on absolute layer mortality data, the mortality index (IM, Eq. 1) was calculated using the equation presented below. The mortality index was classified as normal or high based on descriptive statistics results and literature recommendations, (Dekalb, 2009; Hy-Line, 2009; Lohmman, 2009).
After statistical analyses of the data, the technique of data mining was used to determine if there was any bird mortality pattern as a function of external weather environment.

The process of data mining was divided in different phases, in successive cycles, in order to allow new considerations and revaluations related to the domain and inclusion and exclusion of attributes, according to the method proposed by the CRISP-DM consortium (Chapman et al., 2000). The CRISP-DM method proposed that data mining is carried out according to the following phases:

1) Understanding the knowledge domain to which the study refers to;

2) Knowing and understanding the data bank relative to this domain;

3) Data preparation (cleaning, building, selection, integration, format);

4) Modeling;

5) Evaluation of the results.

W eka ${ }^{\circledR}$ 3-4 (Witten \& Frank, 2005) software program was used for the analysis, and consists of a collection of machine-learning algorithms and data-mining tasks. In the present study, the mining task was classification. The classification algorithm used was J48, an implementation of algorithm C4.5 (Quinlan, 1993; Quilan, 1996), which generates a decision tree or classification tree to classify mortality as normal or high.

The classification tree is a graphical representation of the most relevant variables (attributes) that allow the classification of an object (example). The tree is inversely represented, with the root on the top of the picture and the branches representing the classification rules.

Based on the root node - the first classifying attribute - the mortality classification rules can be described as body $\rightarrow$ head, i.e., antecedent and consequent, presenting the logic connectors IF and AND.

Based on the classification tree, higher interest and applicability rules can be applied according to the model performance, measure by the precision of the model and classification in each class, represented by the proportion of correct hits in the classification expressed in classification matrix, also called confusion matrix, as shown in Table 1 (Gomes, 2002). The true-positive values (Table 1 ) represent values correctly classified in their respective class, whereas false-negative values are those incorrectly classified in that class.

\section{Index of mortality $=\frac{\text { Number of birds killed in the month }}{\text { Number of birds of used in the month }} \times 100$}




\begin{tabular}{|c|c|c|c|c|}
\hline Class & Predicted as C+ & Predicted as C- & Classo precision ${ }^{1}$ & Model precision 2 \\
\hline $\mathrm{C}+$ & $\begin{array}{c}\text { True positive } \\
\text { (Vp) }\end{array}$ & $\begin{array}{l}\text { False negative } \\
\text { (Fn) }\end{array}$ & $V p /(V p+F n) x 100$ & \multirow[t]{2}{*}[(\mathrm{Vp}+\mathrm{Vn})/\mathrm{N}]{$\times 100$} \\
\hline C- & $\begin{array}{c}\text { False positive } \\
\text { (Fp) }\end{array}$ & $\begin{array}{c}\text { True negative } \\
(\mathrm{Vn})\end{array}$ & $\mathrm{Vn} /(\mathrm{Fp}+\mathrm{Vn}) \times 100$ & \\
\hline
\end{tabular}

1 - Expressed in a 0-1 scale. 2 - $\mathrm{N}$ is the number of instances (examples) in the tested set; precision expressed as percentage.

\section{RESULTS AND DISCUSSION}

Monthly maximum and minimum temperatures presented similar behavior, and where higher during the summer months, as shown in the graphs in Figure 1 (a and b). The standard error of these variable, as observed in each point of the graphs, was low, demonstrating the thermal behavior of the region maintained the same behavior during the five studied years.
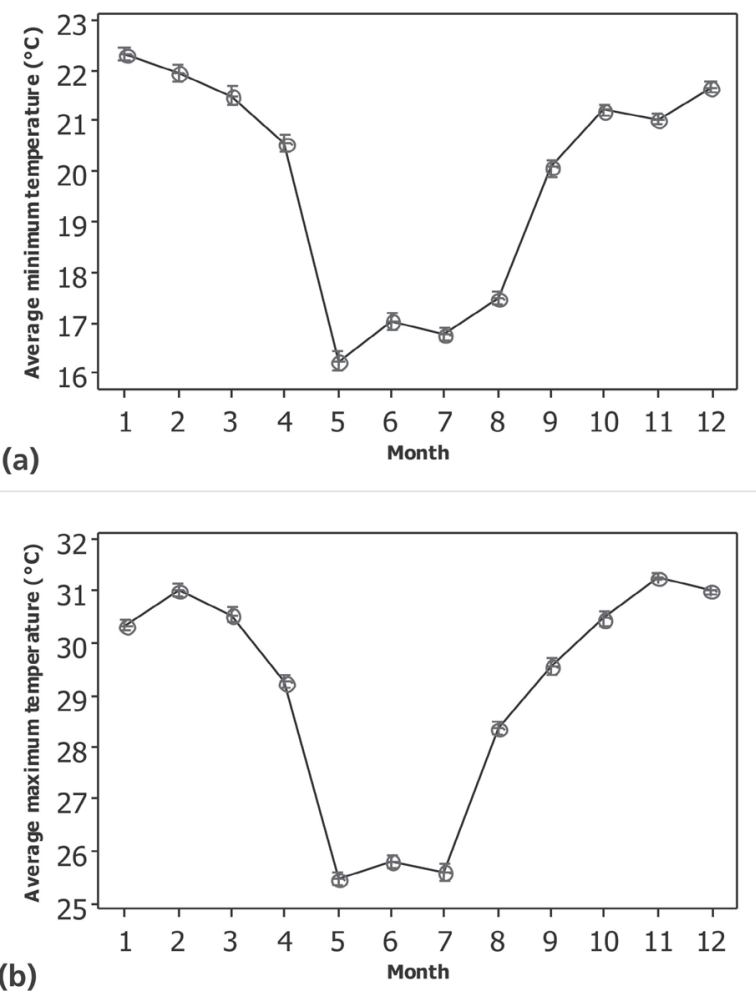

Figure 1 - Annual variation of monthly minimum (a) and maximum (b) temperatures between 2004-2008 in the region of Bastos, SP, Brazil.

Mortality index presented Poisson's distribution, with a very long tail to the right (Figure $2 a$ ), which was expected, as the monthly average of $0.8 \%$ represents normal mortality, whereas the right side represents high mortality.
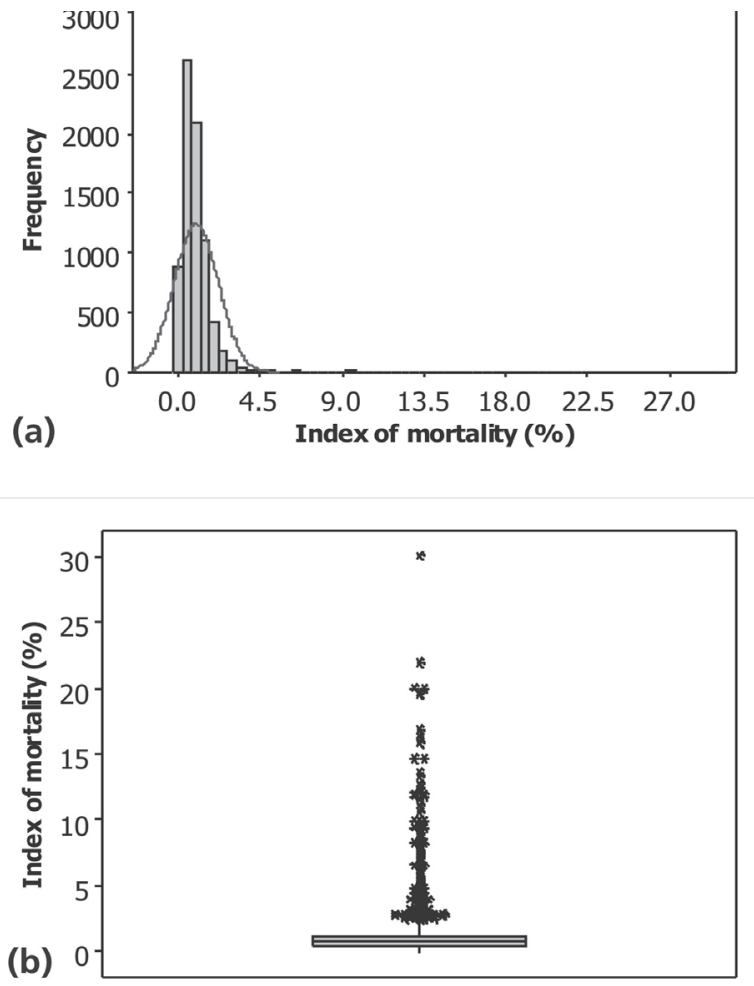

Figure 2 - Histogram of mortality index (a) and mortality index boxplot (b) between 2004-2008 in the region of Bastos, SP, Brazil.

According to the "Protocol of layer welfare" (UBA, 2008 ), mortality should not exceed $1.2 \%$ of the birds housed. Descriptive statistics showed that $72.1 \%$ of the mortality data were below $1.26 \%$ ( $3^{\text {rd }}$ quartile value, Figure $2 \mathrm{~b}$ ), indicating that mortality was sometimes higher than the standards established in the genetic line manuals (Dekalb, 2009; Hy-Line, 2009; Lohmman, 2009; Figure 3b). Therefore, the following mortality index (M I) classes were determined: normal (IM $\leq 1.2 \%$ ) and high (>1.2).

Data mining processing generated the classification tree (Figure 4), which general precision of the model was $62.6 \%$. The high class had a hit precision of $64.1 \%$, and the normal class, $59.9 \%$ (Table 2).

The model presented regular performance for the classification of layer flocks as normal, and therefore 


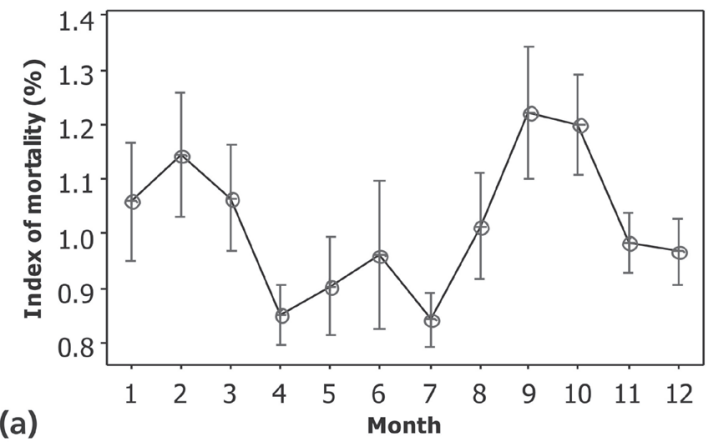

(b)

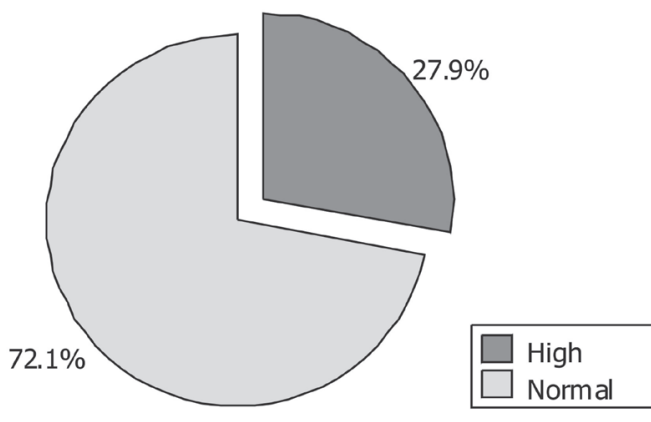

Figure 3 - Annual variation of layer mortality index (a) and mortality index percentage occurence (b) between 2004-2008 in the region of Bastos, SP, Brazil. was not adequate for this classification, but the performance of the model for high mortality was better. Vale et al. (2008), w orking with broiler mortality, similarly to the present study, obtained a classification tree model with a high mortality classification precision of 76 and $83 \%$, depending on the model approach used to select the variables.

\begin{tabular}{lcc}
\hline \multicolumn{3}{l}{ Table 2 - Confusion matrix of the prediction results of the layer } \\
mortality classification model presented in Figure 1. \\
Mortality classes & High & Normal \\
High & 3597 & 1252 \\
Normal & 2014 & 1870 \\
Hits* & $64.1 \%$ & $59.9 \%$ \\
\hline$*$ Classification precision & &
\end{tabular}

* Classification precision.

In the present study, high mortality was the main interest, rather than normal mortality rates. The technique of data mining allows extracting the rules that have higher interest or are more important in a model (Gomes, 2002).

The variables presented in the root node have higher classification power (Witten \& Frank, 2005). In the classification tree presented in Figure 3, flock age was more important in the determination of bird mortality, as it occupied the first root node. Chickens between 24 and 28 weeks of age respond differently to environmental weather conditions as older birds

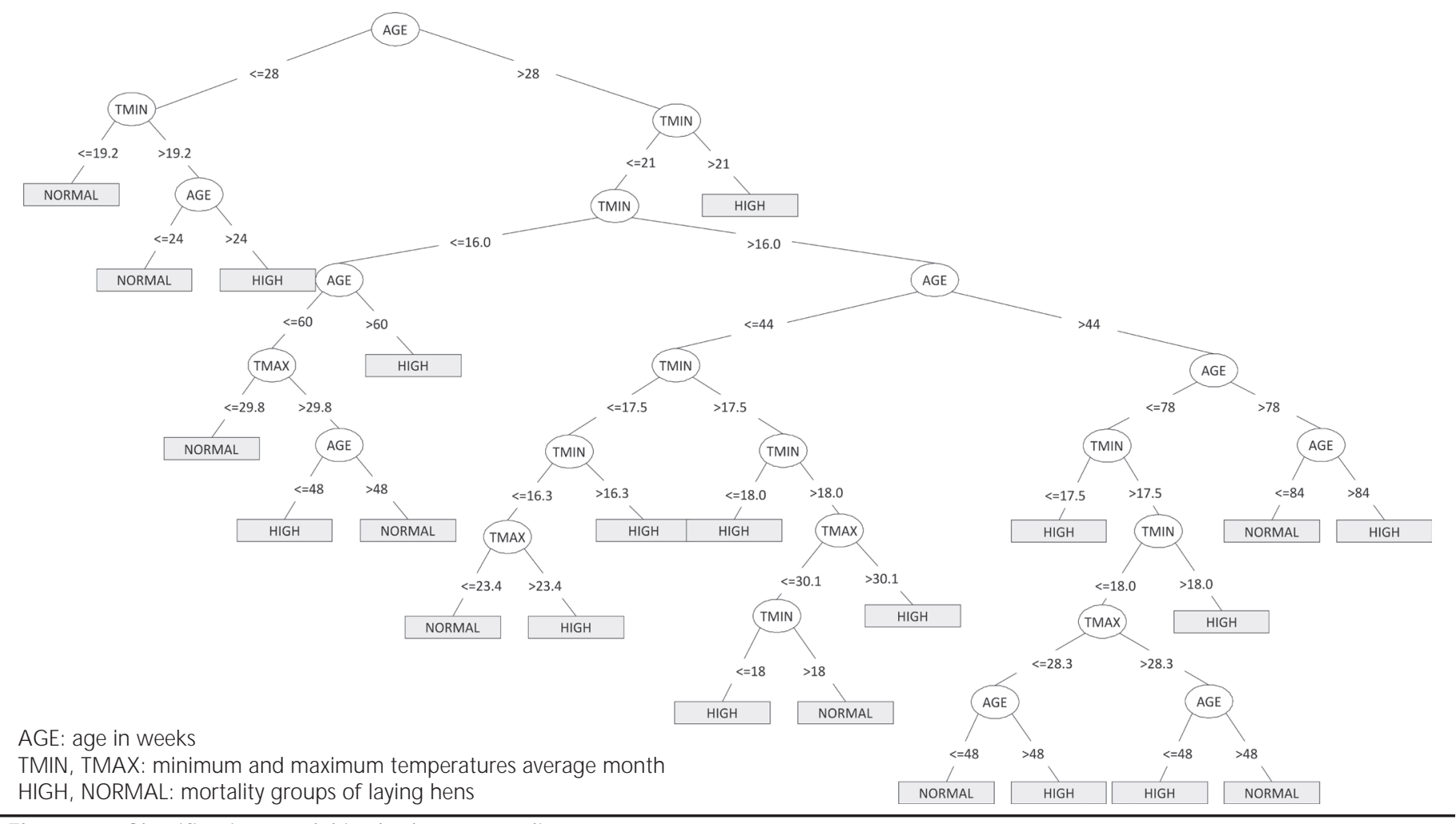

Figure 4 - Classification model in the layer mortality tree. 
are heavier, and therefore, their heat exchange with environment is more difficult as compared to younger birds (Campos, 2000; Furlan \& M acari, 2002). In addition to body weight, 28-w-old layers are achieving the peak of lay, according to most genetic line manuals (Dekalb, 2009; Hy-Line, 2009; Lohmman, 2009), which means that they have higher metabolic activity, and require more nutrients, particularly amino acids (Rocha, 2006; Lin et al., 2006) and energy (Rostagno et al., 2005), generating more metabolic heart, and presenting lower capacity of responding to heat stress.

The other attributes were average minimum and maximum temperatures. According to Yahav et al. (2000), temperature is the most important factor among the causes of heat stress in layer hens.

The left branch of the classification tree in Figure 4 shows the rule of classification of high mortality when age is equal to 28 weeks and higher than 24 weeks. During this rearing phase, a monthly average minimum temperature higher than $19.2{ }^{\circ} \mathrm{C}$ was associated to high mortality. At this age period, layers are still growing, and need to deposit between 160 and $320 \mathrm{~g}$ body weight and to rapidly increase egg production from 5 to $95 \%$ (Dekalb, 2009; Hy-Line, 2009; Lohmman, 20). This physiological condition may thermoregulation difficult.

Figure la shows that the months with minimum temperature higher than 19.2 으 corresponded to the hot season in the region of Bastos, indicating that some management strategies, such as housing layers to have to onset of lay during the cold season, lowers the probability of high mortality. In addition to their physiological status, housing layers with onset of lay during the hot periods of the year may result in worse performance and high mortality (Al-Awadi et al., 1995).

When layers were older than 28 weeks of age, high mortality was observed under different conditions, as shown in the right branch of Figure 4, generating further 13 rules for the classification of high mortality. These rules were age, as first conditioning factor, followed by daily minimum and maximum temperatures.

The classification model of Figure 1, associated to the forecast of monthly average minimum and maximum temperatures for the region of Bastos, allowed building a classification tree and estimating high mortality $(>1.2 \%)$ in layer flocks as a function of flock age in weeks.

Classification rules containing only minimum temperatures and bird age indicate that, in order to build the classification model in Figure 1, these are better predictors of mortality than other variables, such as monthly average maximum temperatures. This is the case of the first rule for high mortality generated in the right branch of the tree in Figure 4 (IF age $>28$ AND average minimum temperature $>21 \stackrel{\circ}{ } \mathrm{C}$, THAN high mortality).

In the present study, the months of October to March presented average minimum temperature higher than $21 \stackrel{\circ}{C}$ and monthly average temperatures higher than $30 \stackrel{\circ}{ }$. These high temperature cause high levels of stress in adult birds (Furlan $\&$ M acari, 2002), which may cause high mortality due to compromised immune response (M ashaly et al., 2004; Mumma et al., 2006).

The remaining of the tree is developed for bird age higher than 28 weeks, and monthly average minimum temperature is lower than $21^{\circ} \mathrm{C}$. In this branch, an interesting rule is observed for birds older than 60 weeks: higher mortality rate is expected when monthly average minimum temperatures are lower or equal to 16 ${ }^{\circ} \mathrm{C}$, that is, a winter condition in that region, as observed in Figure 1a. Mortality after 60 weeks of age may be associated to physiological depletion of the birds, which is at the end of the laying period, with consequent worse immune status and lower resistance to cold extremes (Spinu \& Degen, 1993), particularly in the open-sided poultry houses typical of the studied region.

The other rules established in the classification tree are more complex and difficult to interpret. It is possible that factors such as gradual bird acclimation (Sykes \& Fataftah, 1986; Yahav \& McMurtry, 2001) promote transient adaptation to the seasonal changes of average temperatures.

An alternative for the evaluation of rules in future studies is the application of techniques to evaluate rule interestability - a word used to define the technique of evaluating a rule based on its quality as an useful and applicable rule (Gomes, 2002; Freitas, 1999) and that involves classification precision measurements and judgment by one or several experts in that domain (Gomes, 2002).

The technique of data mining was considered satisfactory in a similar study carried out by Vale et al. (2008), who recorded mortality and weather data on a daily basis. In the present study, as opposed to that of Vale et al. (2008), monthly cumulative mortality may have hindered better analysis performance, as the use of monthly averages of bird mortality and of environmental variables reduces the variation among observations, and may omit mortality during a few days of heat wave during the month. On the other hand, the coherence of the variables used in the model indicate that data were properly collected and allowed higher model precision. Vale et al. (2008) obtained significant precision gains 
when changing the modeling approach using daily information generated by the weather stations. In future studies, data should be collected daily, and mortality should be anticipated in advance, as in the study of Vale (2008).

\section{CONCLUSIONS}

It was possible to build a classification tree for layer mortality based on historical flock and weather data.

The use of data-mining techniques allowed the establishment of patterns in mortality data, generating a classification tree model to estimate losses due to mortality. However, the utilization of daily recorded data may improve the precision of the classification model, which used monthly averages in the present study.

\section{REFERENCES}

Al-Awadi AA, Husseini MD, Diab MF, Al-Nasser AY. Productive performance of laying hens housed in minimal shade floor pens and laying cages under ambient conditions in hot arid regions. Livestock Production Science 1995, 41:263-269.

Campos EJ. Avicultura: razões fatos e divergências. Belo Horizonte: Editora FEPM VZ; 2000. 311p.

Chapman P, Clinton J, Kerber R, Khabaza T, Reinartz T, Shearer C, Wirth R. CRISP-DM 1.0: Step-by-step data mining guide. The CRISPDM consortium. SPSS; 2000. 78p.

Dekalb. M anual de manejo das poedeiras Dekalb. 2009 [cited 2001 out 09]. Available from: www.granjaplanalto.com.

Fayad U, Stolorz P. Data mining and KDD: Promise and challenges. Future Generation Computer Systems 1997; 13:99-115.

Freitas AA. On rule interestingness measures. Knowledge-Based Systems 1999; 12:309-315.

Furlan RL, Macari M. Termorregulação. In: Macari M, Furlan RL, Gonzales E, editores. Fisiologia aviária aplicada a frangos de corte. Jaboticabal: FUNEP; 2002. p.209-230.

Hy-Line International. Commercial manegement guide. Hy-Line; 2009 [cited 2009 out 10]. Available from: www.hyline.com

Gomes AK. Análise do conhecimento extraído de classificadores simbólicos utilizando medidas de avaliação e de interessabilidade [dissertação]. São Carlos (SP): Universidade de São Paulo; 2002.

Lima MGF. Árvore de decisão aplicada a bancos de dados de incubatório de matrizes de postura [dissertação]. Campinas (SP): Universidade Estadual de Campinas; 2007.

Lin H, Jiao HC, Buyse J, Decuypere E. Strategies for preventing heat stress in poultry. World's Poultry Science Journal 2006; 62:71-85.
Lohman. Guia de manejo. Ed. Brasileira; 2009 [cited 2009 out 10]. Available from: www.hyline.com

Marengo JA. Relatório $\mathrm{n}^{\circ}$ 1: Caracterização do clima no século XX e cenários climáticos no Brasil e na América do Sul para o século XXI derivados dos modelos globais de clima do IPCC. São Paulo: Ministério do Meio Ambiente, CPTEC/INPE; 2007.

Mashaly MM, Hendricks GL, Kalama MA, Gehad AE, Abbas AO, Patterson PH. Effect of heat stress on production parameters and immune responses of commercial laying hens. Poultry Science 2004; 83:889-894.

M umma JO, Thaxton JP, Vizzier-Thaxton Y, Dodson WL. Physiological stress in laying hens. Poultry Science 2006; 85:761-769.

Nardone A, Ronchi B, Laceteraand N, Bernabucci U. Climatic effects on productive traits in livestock. Veterinary Research Communications 2006; 30(1):75-81.

Quinlan JR. C4.5: Programs for machine learning. M organ Kaufmann Publishers; 1993. 302 p.

Quinlan JR. Improved use of continuous attributes in C4.5. Journal of Artificial Intelligence Research 1996; 4:77-90.

Rocha TC. Níveis de lisina digestível em rações para poedeiras leves no período de produção [dissertação]. Viçosa (M G): Universidade Federal de Viçosa; 2006.

Rolim GS, Camargo MBP, Lania DG, Moraes JFL. Classificação climática de Köppen e de Thornthwaite e sua aplicabilidade na determinação de zonas agroclimáticas para o estado de São Paulo. Bragantina 2007; 6(4):711-720.

Rostagno HS, Albino LFT, Donzele JL, Gomes PC, Ferreira AS, Oliveira RF, Lopes DC. Exigências nutricionais das aves. In: Rostagno HS, editor. Tabelas brasileiras para aves e suínos: composição de alimentos e exigências nutricionais. Viçosa: Ed. UFV; 2005. p.53-84.

Salgado DD. Avaliação de risco à produção avícola no Estado de São Paulo frente ao aquecimento global [tese]. Campinas (SP): Universidade Estadual de Campinas; 2008.

Spinu M, Degen AA. Effect of cold stress on performance and immune responses of bedouin and white leghorn hens. British Poultry Science 1993; 34:177-185.

Sykes AH, Fataftah ARA. Acclimatisation of the fow I to intermittent acute. British Poultry Science 1986; 27:289-300.

União Brasileira de Avicultura. Protocolo de bem-estar de poedeiras. Brasília: UBA; 2008.

União Brasileira de Avicultura. Relatório Anual 2009. Brasília:UBA; 2008

Vale M M, Moura DJ, Nääs IA, Oliveira SRM, Rodrigues LH. Data mining to estimate broiler mortality when exposed to heat wave. Scientia Agrícola; 65(3):223-229

Vale M M . Previsão da ocorrência e caracterização de ondas de calor 
com impacto na mortalidade de frangos de corte [tese] Campinas (SP): Universidade Estadual de Campinas; 2008.

Yahav S, McM urtry JP. Thermotolerance acquisition in broiler chickens by temperature conditioning earlyin Life -The effect of timing and ambient temperature. Poultry Science 2001; 80:16621666.

Yahav S, Shinder D, Razpakovski V, Rusal M, Bar A. Lack of response of laying hens to relative humidity at high ambient temperature. British Poultry Science 2000; 41:660-663.

Witten $\mathrm{IH}$, Frank E. Data mining: practical machine learning tools and techniques. 2nd ed. San Francisco: Morgan Kaufmann; 2005. 